\title{
A specific p47phox-serine phosphorylated by convergent MAPKs mediates neutrophil NADPH oxidase priming at inflammatory sites
}

Pham My-Chan Dang, 1,2 Allan Stensballe, ${ }^{3}$ Tarek Boussetta, 1,2 Houssam Raad,1,2 Cedric Dewas, 1,2 Yolande Kroviarski, ${ }^{1,2,4}$ Gilles Hayem, ${ }^{4}$ Ole N. Jensen, ${ }^{3}$ Marie-Anne Gougerot-Pocidalo,, ${ }^{1,2,4}$ and Jamel El-Benna1,2

${ }^{1}$ INSERM, U.773, CRB3, Paris, France. ${ }^{2}$ Université Paris 7 - Denis Diderot, Site Bichat, Paris, France. ${ }^{3}$ Protein Research Group, Department of Biochemistry and Molecular Biology, University of Southern Denmark, Odense, Denmark. ${ }^{4}$ Rheumatology Department and Assistance Publique Hôpitaux de Paris, Centre Hospitalier Universitaire Xavier Bichat, CIB Phenogen, Paris, France.

\begin{abstract}
Neutrophil NADPH oxidase plays a key role in host defense and in inflammation by releasing large amounts of superoxide and other ROSs. Proinflammatory cytokines such as GM-CSF and TNF- $\alpha$ prime ROS production by neutrophils through unknown mechanisms. Here we used peptide sequencing by tandem mass spectrometry to show that GM-CSF and TNF- $\alpha$ induce phosphorylation of Ser345 on $\mathrm{p} 47^{\mathrm{phox}}$, a cytosolic component of NADPH oxidase, in human neutrophils. As Ser345 is located in the MAPK consensus sequence, we tested the effects of MAPK inhibitors. Inhibitors of the ERK1/2 pathway abrogated GM-CSF-induced phosphorylation of Ser345, while p38 MAPK inhibitor abrogated TNF- $\alpha$-induced phosphorylation of Ser345. Transfection of HL-60 cells with a mutated $\mathrm{p} 47 \mathrm{phox}$ (S345A) inhibited GM-CSF- and TNF- $\alpha$-induced priming of ROS production. This event was also inhibited in neutrophils by a cell-permeable peptide containing a

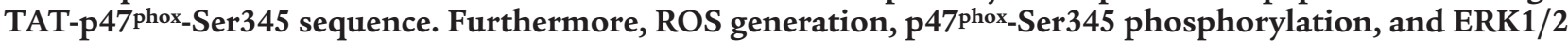
and p38 MAPK phosphorylation were increased in synovial neutrophils from rheumatoid arthritis (RA) patients, and TAT-Ser345 peptide inhibited ROS production by these primed neutrophils. This study therefore identifies convergent MAPK pathways on Ser345 that are involved in GM-CSF- and TNF- $\alpha$-induced priming of neutrophils and are activated in RA. Inhibition of the point of convergence of these pathways might serve as a novel antiinflammatory strategy.
\end{abstract}

\section{Introduction}

Neutrophils play a key role in host defenses against invading microorganisms and have a major role in inflammation (1-4). In response to a variety of agents, they release large quantities of superoxide anion $\left(\mathrm{O}_{2^{-}}\right)$and other ROSs in a phenomenon known as the respiratory burst (4). Neutrophil production of $\mathrm{O}_{2}{ }^{-}$is dependent on activation of NADPH oxidase, a multicomponent enzyme system that catalyzes NADPH-dependent reduction of oxygen to $\mathrm{O}_{2^{-}}(5-7)$. In resting cells, NADPH oxidase is inactive, and its components are distributed between the cytosol and membranes. When cells are activated, the cytosolic components of the phagocyte oxidase (phox), such as p47phox, p67phox, p40phox, and Rac2, migrate to the membranes, where they associate with the membrane-bound component (flavocytochrome b558) to assemble the catalytically active oxidase (8-11). Upon NADPH oxidase activation, $\mathrm{p} 47^{\text {phox }}, \mathrm{p} 67^{\text {phox }}, \mathrm{p} 40^{\text {phox }}$, and $\mathrm{p} 22^{\text {phox }}$ become phosphorylated (12-16). p47phox phosphorylation on several serines plays a pivotal role in oxidase activation in intact cells (17-19). As oxidants produced by NADPH oxidase are highly toxic not only for infectious agents but also for neighboring host tissues, tight regulation of the enzyme complex is necessary to control their production. Phosphorylation/dephosphorylation of the oxidase subunits is one such regulatory mechanism. Various kinases have been shown

Nonstandard abbreviations used: $\mathrm{fMLP}$, formyl-methionyl-leucyl-phenylalanine; phox, phagocyte oxidase.

Conflict of interest: The authors have declared that no conflict of interest exists. Citation for this article: J. Clin. Invest. 116:2033-2043 (2006). doi:10.1172/JCI27544. to phosphorylate $\mathrm{p} 47^{\text {phox }}$ in vitro, but the regulatory pathways involved in the in vivo priming and activation steps are unclear.

Neutrophil $\mathrm{O}_{2}-$ production can be potentiated by prior exposure to "priming" agents such as the proinflammatory cytokines GMCSF, TNF- $\alpha$, and IL-8 $(20,21)$. These cytokines inherently induce a very weak oxidative response by neutrophils, but they strongly enhance neutrophil release of ROS on exposure to a secondary applied stimulus such as bacterial $\mathrm{N}$-formyl peptides $(22,23)$. The intimate mechanisms involved in the priming process are poorly understood. Some studies have suggested that priming is regulated at the receptor and heterotrimeric G-protein levels $(24,25)$ or through an increase in cytochrome b558 expression (26-28). We and others have reported that priming of the human neutrophil respiratory burst by GM-CSF, LPS, and TNF- $\alpha$ is associated with partial phosphorylation of the cytosolic NADPH oxidase component p47phox $(26,29-31)$, but the identity of the phosphorylated serines and the kinases involved in their phosphorylation remained to be discovered. No direct link between the phosphorylation of $\mathrm{p} 47_{\mathrm{phox}}$ and the priming process has yet been established.

The GM-CSF receptor is composed of 2 chains, designated $\alpha$ and $\beta(32,33)$. Engagement of GM-CSF with its receptor activates a number of signal transduction pathways in human neutrophils, including protein tyrosine kinase, PI3K (34-36), and the MAPK family members ERK1/2 (37-40). GM-CSF binding to its receptor induces and increases the binding of the protein tyrosine kinase JAK2 and the src-tyrosine kinase lyn to the intracellular domain of the receptor $(34,41,42)$. These tyrosine kinases transduce the GM-CSF signal by phosphorylating other 

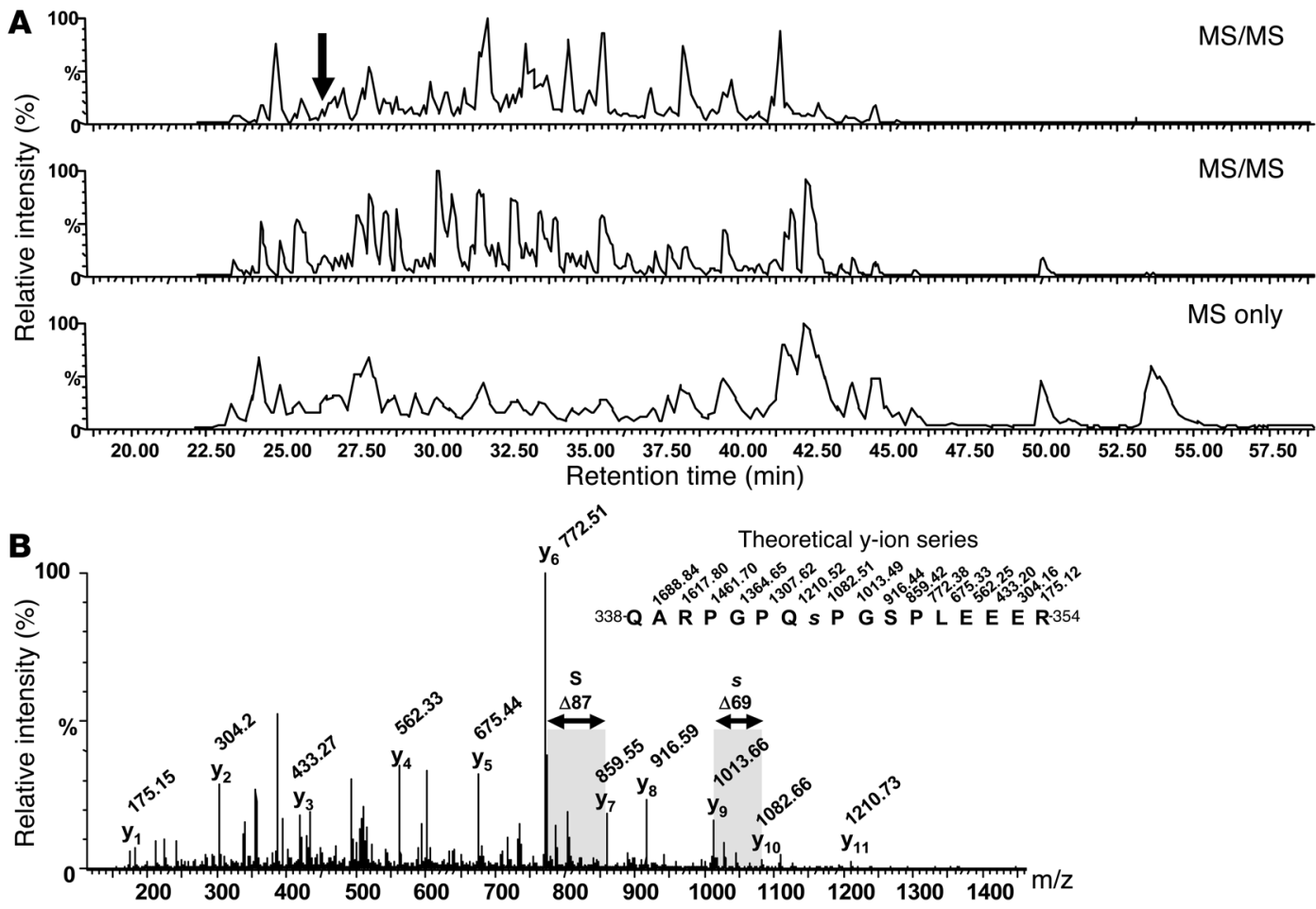

Figure 1

Mass spectrometry analysis of GM-CSF-induced p47phox phosphorylation: Ser345 was phosphorylated in primed human neutrophils. (A) LC-MS/MS analysis of an aliquot of the p47phox tryptic peptide mixture (gradient: 0-38\% acetonitrile in 35 minutes). The 2 upper panels depict the base peak chromatograms of electrospray ionization MS/MS experiments performed during the analysis in data-dependent acquisition mode. The lower panel represents the base peak chromatogram of the MS survey scans only. The arrow indicates the elution time of the phosphopeptide that was sequenced by MS/MS. (B) Identification of the phosphorylated peptide QARPGPQ[pS]PGSPLEEER (amino acids 338-354). The MS/MS spectrum displayed a near-complete $y$-ion series that reflects the amino acid sequence and the position of the phosphate group at Ser345. The elimination of phosphoric acid from the phosphoserine residue during MS/MS generated a dehydroalanine residue at the position corresponding to Ser345 (s; residue mass, $69 \mathrm{Da}$ ). The spectrum also demonstrated that the Ser348 residue (S) was not phosphorylated (residue mass, $87 \mathrm{Da}$ ).

proteins such as STAT, PKB, and PI3K. TNF- $\alpha$ exerts its cellular effects by binding to its 2 receptors, p55 and p75. Neutrophils express both receptor types (43), which are linked to different signaling pathways such as p38 $\operatorname{MAPK}(27,39)$. The molecular mechanisms by which GM-CSF and TNF- $\alpha$ prime the respiratory burst in human neutrophils are not fully known.

RA is a systemic inflammatory disorder most commonly targeting the joints. The pathophysiology of RA involves dysregulated cytokine production and neutrophil accumulation in synovial fluid (44). Both excessive production of ROS and release of degradative enzymes by neutrophils have been implicated in rheumatoid tissue damage $(4,45)$.

The aims of this study were to identify the p47phox site that is phosphorylated during TNF- $\alpha$ - and GM-CSF-induced priming of the oxidative burst; to determine the protein kinase(s) involved in this process; and to determine whether these phosphorylation events occur during an inflammatory disease. We used tandem mass spectrometry (MS/MS) to show that the phosphorylation target on $\mathrm{p} 47 \mathrm{phox}$ after GM-CSF and TNF- $\alpha$ exposure is Ser345. We also showed that ERK1/2 are the protein kinases involved in GM-CSF-induced phosphorylation of Ser345, while p38 MAPK controls TNF- $\alpha$-induced phosphorylation of the same site. In addition, these phosphorylation pathways were activated in neutrophils isolated from synovial fluid of RA patients. We also showed that phosphorylation of Ser345 on p47phox is directly related to GM-CSF- and TNF- $\alpha$-induced priming of ROS production. These results show that Ser345 is a point of convergence used by different MAPK activities to induce priming of ROS production. The selective phosphorylation of Ser345 on p47phox is, to our knowledge, a novel priming mechanism and might serve as a novel antiinflammatory target.

\section{Results}

Identification of the GM-CSF- and TNF- $\alpha$-induced $p 47^{p h o x}$ phosphorylation target site. In formyl-methionyl-leucyl-phenylalanine- (fMLP-) or PMA-stimulated human neutrophils, $\mathrm{p} 47 \mathrm{phox}$ is phosphorylated on several serines located between Ser303 and Ser379 $(17,18)$. In contrast, in GM-CSF- or TNF- $\alpha$-primed human neutrophils, $\mathrm{p} 47$ phox is partially phosphorylated on a common peptide that could contain several serines as potential targets of the GM-CSF- and TNF- $\alpha$ priming cascades $(29,30)$. In order to identify the $\mathrm{p} 47 \mathrm{phox}$ site(s) that are phosphorylated upon GM-CSF or TNF- $\alpha$ exposure, we immunopurified p47phox from GM-CSF- and TNF- $\alpha$-treated cells $\left(5 \times 10^{8}\right)$ and analyzed it by mass spectrometry. The protein was digested with trypsin and endoproteinase Lys-C, and the resulting peptide mixtures were analyzed by liquid chromatography-elec- 

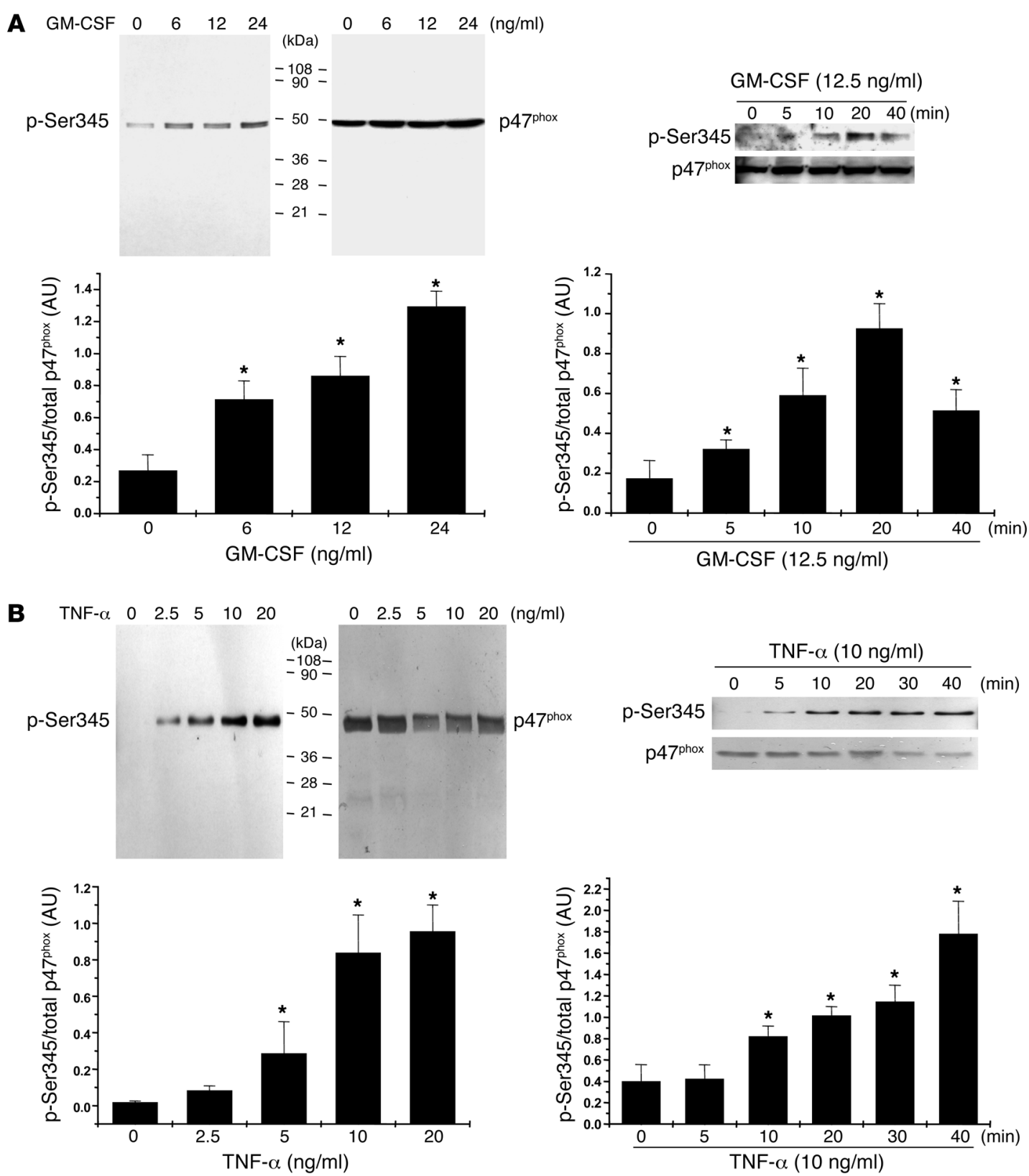

Figure 2

Use of an antibody to phospho-Ser345 demonstrates that GM-CSF and TNF- $\alpha$ induce phosphorylation of p47phox on Ser345 in a concentrationand time-dependent manner. (A) Neutrophils $\left(1 \times 10^{7} \mathrm{cells} / \mathrm{ml}\right)$ were incubated with various concentrations of GM-CSF for 20 minutes or were incubated with GM-CSF $(12.5 \mathrm{ng} / \mathrm{ml})$ for the times indicated. Cells were lysed, and proteins from $4 \times 10^{5}$ cells were analyzed with SDS-PAGE and immunoblotting with anti-phospho-Ser345 antibody (p-Ser345) or anti-p47phox antibody (p47phox). (B) Neutrophils $\left(1 \times 10^{7}\right.$ cells/ml) were incubated with various concentrations of TNF- $\alpha$ for 20 minutes or were incubated with TNF- $\alpha$ (10 ng/ml) for the times indicated. Cells were lysed, and proteins from $4 \times 10^{5}$ cells were analyzed with SDS-PAGE and immunoblotting with anti-phospho-Ser345 antibody or anti-p47phox antibody. Western blots from different experiments were scanned; phosphorylated and total p47phox were quantified by densitometry; and the intensity of phosphorylated $\mathrm{p} 47^{\text {phox }}$ was corrected for the amount of p47phox. Results are expressed as mean \pm SEM $(n=3)$. ${ }^{*} P<0.05$ compared with untreated neutrophils or time 0 minutes.

trospray ionization-MS/MS with data-dependent acquisition. The phosphopeptide (amino acids 338-354) was detected at 26 minutes and was automatically selected for sequencing by MS/MS (Figure 1). (The same result was obtained with GM-CSF and TNF- $\alpha$, but only the GM-CSF result is shown here). The presence of a phosphoserine at position 345 (QARPGPQ[pS]PGSPLEEER) was revealed by MS/MS, based on the mass difference of $69 \mathrm{Da}$ (dehydroalanine) between the $y_{9}$ and $y_{10}$ fragment ions (Figure 1B). Dehydroalanine is generated upon phosphoric acid elimination from phosphoserine and is commonly observed in MS/MS $(46,47)$. The MS/MS spectrum also demonstrated that Ser348 was not phosphorylated, as dehydroalanine was not detected at this position. 

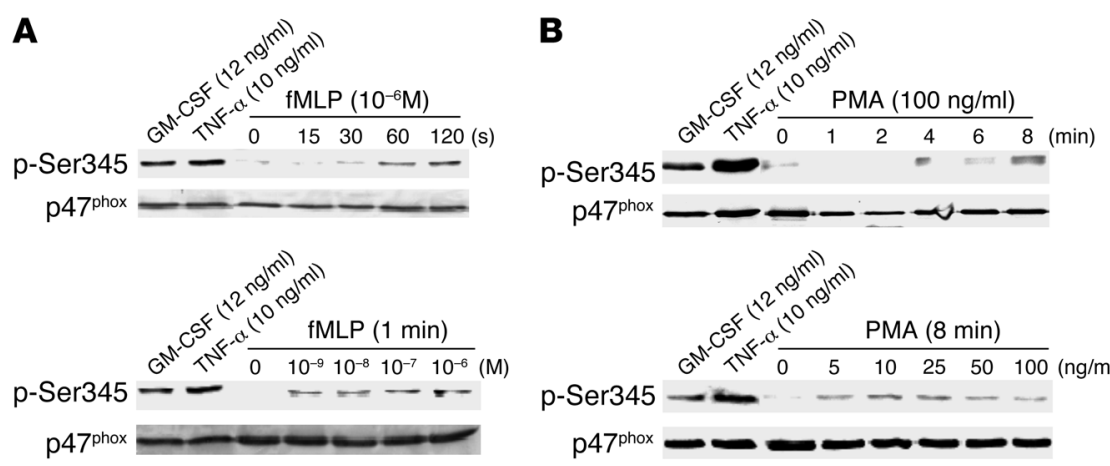

\section{Figure 3}

Effect of different neutrophil agonists on the phosphorylation of Ser345. Neutrophils $\left(1 \times 10^{7}\right.$ cells/ $\mathrm{ml})$ were incubated with $\mathrm{GM}-\mathrm{CSF}(12.5 \mathrm{ng} / \mathrm{ml})$ for 20 minutes, TNF- $\alpha(10 \mathrm{ng} / \mathrm{ml})$ for 20 minutes, and different concentrations of PMLP (A) or PMA (B) for different time periods. Cells were then lysed, and proteins from $4 \times 10^{5}$ cells were analyzed with SDS-PAGE and immunoblotting with antiphospho-Ser345 antibody or anti-p47 phox antibody. Data are representative of 3 independent experiments using cells from different donors.
Use of an antibody against phospho-Ser345 demonstrates that GM-CSF and TNF- $\alpha$ induce Ser 345 phosphorylation. To examine Ser345 phosphorylation status in cellular extracts, we prepared a polyclonal antibody directed against phospho-Ser345 by using as antigen the peptide QARPGPQ[pS]PGSPLEEER (p47phox amino acids 338-354). Western blot analysis of whole-cell lysates from GM-CSF- or TNF- $\alpha$-treated neutrophils (from as few as $4 \times 10^{5}$ cells) showed (Figure 2, A and B; p-Ser345) that this antibody was highly specific for phosphorylated $\mathrm{p} 47 \mathrm{phox}$, as it did not recognize other phosphorylated proteins. Total $\mathrm{p} 47^{\mathrm{phox}}$ protein was detected with an antibody that recognizes the nonphosphorylated as well as the phosphorylated protein (Figure 2, A and B; p47phox). Phosphorylated and total $\mathrm{p} 47^{\mathrm{phox}}$ from several experiments were quantified by densitometry and the amount of phosphorylated $\mathrm{p} 47$ phox corrected for the amount of $\mathrm{p} 47 \mathrm{phox}$. Together, the results show that GM-CSF- and TNF- $\alpha$-induced $\mathrm{p} 47^{\text {phox }}$ phosphorylation at Ser345 were both concentration and time dependent and closely matched the priming effects of GM-CSF and TNF- $\alpha$ on $\mathrm{O}_{2}{ }^{--}$production $(29,30)$ (Figure 2, A and B).

We next examined whether other agents known to activate neutrophils such as the chemoattractant peptide fMLP and the protein kinase C activator PMA could induce Ser345 phosphorylation. Time course and dose-response studies (Figure 3, A and B) showed that fMLP and PMA weakly induced Ser345 phosphorylation as compared with the phosphorylation induced by the proinflammatory cytokines GM-CSF and TNF- $\alpha$. Specific detection of $\mathrm{p} 47^{\mathrm{phox}}$ with an antibody that recognizes the nonphosphorylated as well as the phosphorylated protein showed that the same amount of $\mathrm{p} 47 \mathrm{phox}$ was present in each sample. These results suggest that Ser345 is more strongly phosphorylated during GM-CSF- or TNF- $\alpha-$ induced priming than in stimulatory conditions.

Effect of tyrosine kinase and MAPK inhibitors on GM-CSF- and TNF- $\alpha-$ induced $p 47^{\text {phox }}$ phosphorylation. Myeloid cells such as neutrophils are terminally differentiated, short-lived cells and are resistant to transfection. An alternative strategy to study the role of specific enzymes is to use cell-permeant pharmacologic inhibitors. In previous studies $(29,30)$ we showed, by ${ }^{32} \mathrm{P}$ labeling, that the broad-range protein tyrosine kinase inhibitor genistein inhibited GM-CSF- and TNF- $\alpha$-induced p47phox phosphorylation. To verify that Ser345 phosphorylation detected with the specific antibody is controlled by the same upstream tyrosine kinases, we tested the effects of genistein on this process. First, $\mathrm{p} 47 \mathrm{phox}$ from ${ }^{32} \mathrm{P}$-labeled neutrophils $\left(5 \times 10^{7}\right.$ cells) was immunoprecipitated with anti-p47phox and analyzed by SDS-PAGE, Western blotting, and autoradiography (Figure $4, \mathrm{~A}$ and $\mathrm{B} ;\left[{ }^{32} \mathrm{P}\right] \mathrm{p} 47 \mathrm{phox}$ ). Second, total cell lysates $\left(4 \times 10^{5}\right.$ cells) were analyzed by SDS-PAGE and
Western blotting with the anti-phospho-Ser345 antibody (Figure 4, A and B; p-Ser345). Both methods showed that genistein inhibited GM-CSF- and TNF- $\alpha$-induced $\mathrm{p} 47^{\text {phox }}$ phosphorylation, confirming that the anti-phospho-Ser345 antibody recognizes the phosphorylated site on $\mathrm{p} 47$ phox induced by GM-CSF and TNF- $\alpha$ and that a genistein-sensitive tyrosine kinase controls this event.

As Ser345 is located in a sequence recognized and phosphorylated by MAPK (-PXSP-), we examined which MAPK was involved in GM-CSF- and TNF- $\alpha$-induced $\mathrm{p} 47 \mathrm{Phox}^{\text {ph }}$ phosphorylation at Ser345 by testing the effects of different MAPK inhibitors. As GM-CSF and TNF- $\alpha$ induce the activation of ERK1/2 and p38 MAPK, respectively, in suspended human neutrophils (Figure 5A and refs. 39, 40), we used PD98059 and UO126, which inhibit MEK1/2 (the upstream activator of ERK1/2) $(48,49)$ and also SB203580, a p38 MAPK inhibitor (50), to analyze the role of these 2 MAPK pathways in $\mathrm{p}^{4} 7^{\text {phox }}$ phosphorylation in intact neutrophils. Neutrophils were incubated for 45 minutes with PD98059 $(50 \mu \mathrm{M}), \mathrm{UO} 126(10 \mu \mathrm{M})$, or SB203580 $(10 \mu \mathrm{M})$, then treated with GM-CSF or TNF- $\alpha$. p47phox phosphorylation status was analyzed by comparing the results of the 2 methods ( ${ }^{32} \mathrm{P}$ labeling and antiphospho-Ser345 antibody). As shown in Figure 5B, PD98059 and UO126 abrogated $\mathrm{p} 47^{\text {phox }}$ phosphorylation on Ser345 in parallel with the inhibition of ERK1/2 phosphorylation (Figure 5B;
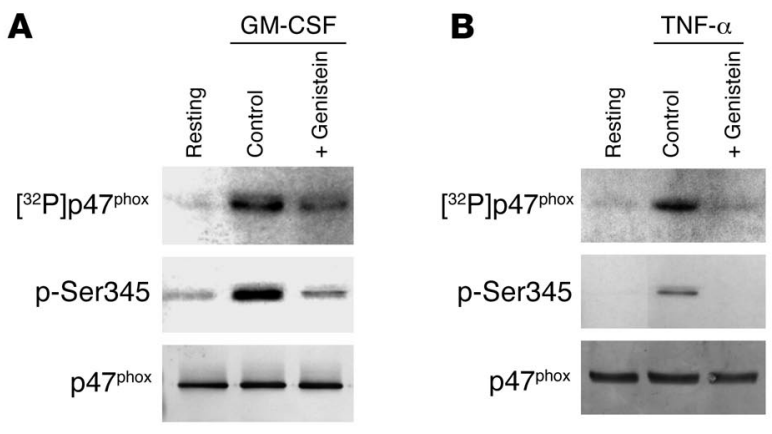

\section{Figure 4}

Effect of genistein, a protein tyrosine kinase inhibitor, on GM-CSF- and TNF- $\alpha$-induced $p 47^{\text {phox }}$ phosphorylation. Neutrophils were incubated without (Control) or with $100 \mu \mathrm{M}$ genistein for 30 minutes, then with $12.5 \mathrm{ng} / \mathrm{ml} \mathrm{GM}-\mathrm{CSF}$ (A) or $10 \mathrm{ng} / \mathrm{ml} \mathrm{TNF-} \alpha$ for 20 minutes (B). p47phox from ${ }^{32} \mathrm{P}$-labeled neutrophils $\left(5 \times 10^{7}\right.$ cells) was immunoprecipitated with anti-p47phox antibody and analyzed by SDS-PAGE, Western blotting, and autoradiography $\left.\left({ }^{32} \mathrm{P}\right] \mathrm{p} 47^{\mathrm{phox}}\right)$. Total cell lysates $\left(4 \times 10^{5}\right.$ cells) from unlabeled treated cells were also analyzed by SDS-PAGE and Western blotting using the anti-phospho-Ser345 antibody or antip47 phox antibody. Data are representative of 4 experiments. 
A

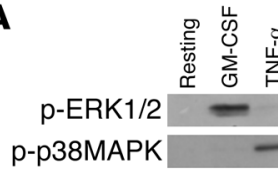

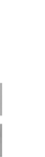

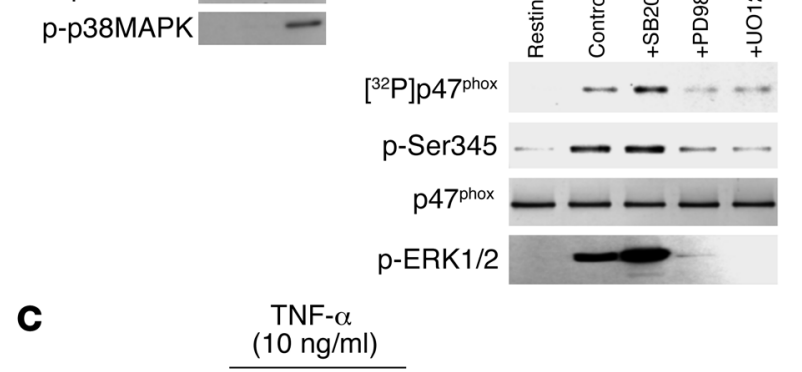

B

GM-CSF $(12.5 \mathrm{ng} / \mathrm{ml})$ $(10 \mathrm{ng} / \mathrm{ml})$

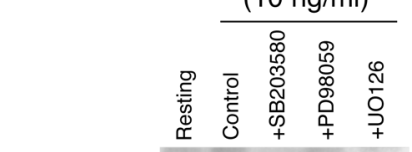

[32P]p47 phox

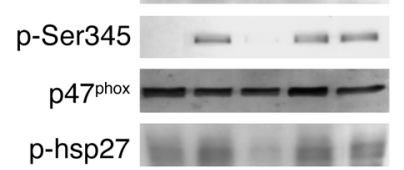

p-ERK1/2) induced by GM-CSF. SB203580 had no inhibitory effect; it rather moderately enhanced GM-CSF-induced phosphorylation of p47phox and ERK1/2, an effect not further examined here. This strongly pointed to ERK1/2 as the kinases involved in p47phox phosphorylation on Ser345 in GM-CSF-primed human neutrophils. However, with regard to TNF- $\alpha$-treated neutrophils, the p38 MAPK inhibitor SB203580 inhibited phosphorylation of p47phox on Ser345, but the MEK1/2 inhibitors (PD98059 and U0126) had no effects (Figure 5C). In these conditions SB203580 inhibited p38 MAPK activity, as shown by inhibition of the phosphorylation of hsp27, a known substrate of MAPK-activated kinase 2, which is a downstream target of p38 MAPK. In all these experiments, specific detection of p47phox, ERK1/2, and hsp27 with specific antibodies that recognize the nonphosphorylated as well as the phosphorylated proteins showed that the same amounts of each protein were present in each sample (Figure 5, A-C, and data not shown). All these results suggest that ERK1/2 are the kinases involved in $\mathrm{p} 47^{\text {phox }}$ phosphorylation on Ser345 in GM-CSF-primed human neutrophils, while p38 MAPK is the kinase involved in $\mathrm{p} 47^{\mathrm{phox}}$ phosphorylation on Ser345 in TNF- $\alpha-$ primed human neutrophils. These 2 pathways could be convergent on the phosphorylation of $\mathrm{p} 47^{\text {phox }}$ on this specific site.

\section{Figure 6}

Mutation of $\mathrm{p} 47^{\text {phox }}$-Ser345 to Ala inhibits the priming process in HL-60 cells. HL-60 cells were transfected with a plasmid that encodes WT p47 phox or p47 phox in which Ser345 was mutated to alanine (S345A) and differentiated into neutrophils by DMSO. (A) A total of $5 \times 10^{5}$ nondifferentiated and differentiated cells were lysed and analyzed by SDS-PAGE and Western blotting. p47 phox and p67phox were detected with specific antibodies and HRP-labeled goat anti-rabbit antibody. (B) Differentiated HL-60 cells were washed, incubated for 5 hours in RPMI, washed in PBS, then treated with TNF- $\alpha(10 \mathrm{ng} / \mathrm{ml})$ or GMCSF $(12 \mathrm{ng} / \mathrm{ml})$ for 15 minutes in Hanks buffer. ROS generation was measured by chemiluminescence after stimulation with fMLP $\left(10^{-7} \mathrm{M}\right)$. Data are presented as mean $\pm \operatorname{SEM}(n=5)$. ${ }^{\star} P<0.05$ compared with WT transfected cells.

\section{Figure 5}

Effect of MAPK inhibitors on GM-CSF- and TNF- $\alpha$-induced $p 47^{\text {phox }}$ and MAPK activation. (A) Neutrophils $\left(1 \times 10^{7} \mathrm{cells} / \mathrm{ml}\right)$ were incubated with GM-CSF $(12.5 \mathrm{ng} / \mathrm{ml})$ or TNF- $\alpha(10 \mathrm{ng} / \mathrm{ml})$ for $20 \mathrm{~min}-$ utes and lysed, and proteins from $4 \times 10^{5}$ cells were analyzed with SDS-PAGE and immunoblotting with anti-phospho-ERK1/2 or antiphospho-p38 antibody (p-p38MAPK). (B and C) Neutrophils were incubated with SB203580 (10 $\mu \mathrm{M})$, PD98059 (50 $\mu \mathrm{M})$, or UO126 $(10 \mu \mathrm{M})$ for 30 minutes, then treated with GM-CSF (B) or TNF- $\alpha(\mathbf{C})$ for 20 minutes. p47phox from ${ }^{32} \mathrm{P}$-labeled neutrophils $\left(5 \times 10^{7}\right.$ cells $)$ was immunoprecipitated with anti-p47phox antibody and analyzed by SDS-PAGE, Western blotting, and autoradiography. Total cell lysates $\left(4 \times 10^{5}\right.$ cells $)$ from unlabeled cells were also analyzed by SDS-PAGE and Western blotting with anti-phospho-Ser345 antibody or anti-phospho-ERK1/2 antibody (p-ERK1/2), which reflects MEK1/2 activity. p38 MAPK activity was assessed by in vitro phosphorylation of hsp27, as described in Methods. Data are representative of 3 experiments.

Mutation of Ser345 to Ala inhibits the priming process in HL-60 cells. To test whether phosphorylation of Ser345 of p 47 phox is required for NADPH oxidase priming in intact cells, we used a plasmid that encodes $\mathrm{p} 47 \mathrm{phox}$ in which Ser345 was mutated to alanine (S345A), as compared with a plasmid that encodes WT p47phox. Because neutrophils are terminally differentiated, short-lived cells that are resistant to transfection, we used HL-60 cells, which can be transfected and differentiated into neutrophil-like cells. Results showed (Figure 6A) that nondifferentiated transfected HL-60 cells expressed the same amount of WT and mutated p47phox but not p67phox, while after differentiation an increase in $\mathrm{p} 47 \mathrm{phox}$ expression and in $\mathrm{p} 67 \mathrm{phox}$ expression occurred. ROS production by differentiated HL-60 cells transfected with WT $447^{\text {phox }}$ was primed by TNF- $\alpha$ or GM-CSF. In contrast, ROS production by differentiated HL-60 cells transfected with the S345A-p47phox mutant was not primed by TNF- $\alpha$ or GM-CSF, as the level of ROS production after TNF- $\alpha$ or GM-CSF
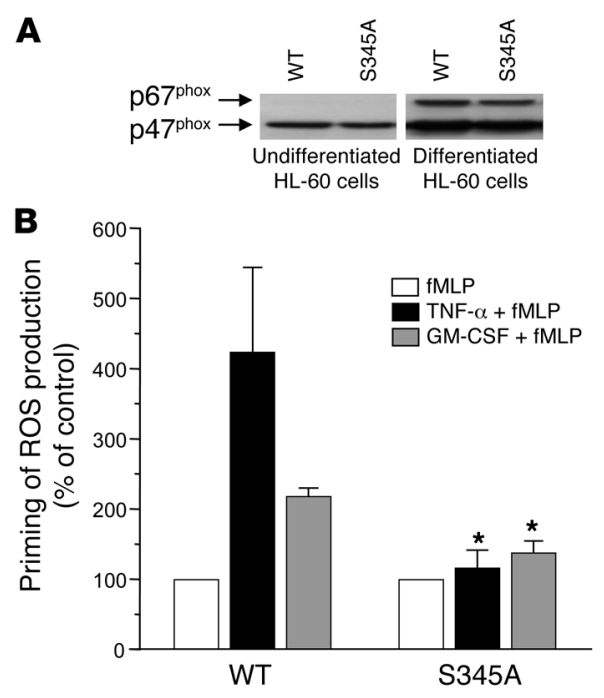
A
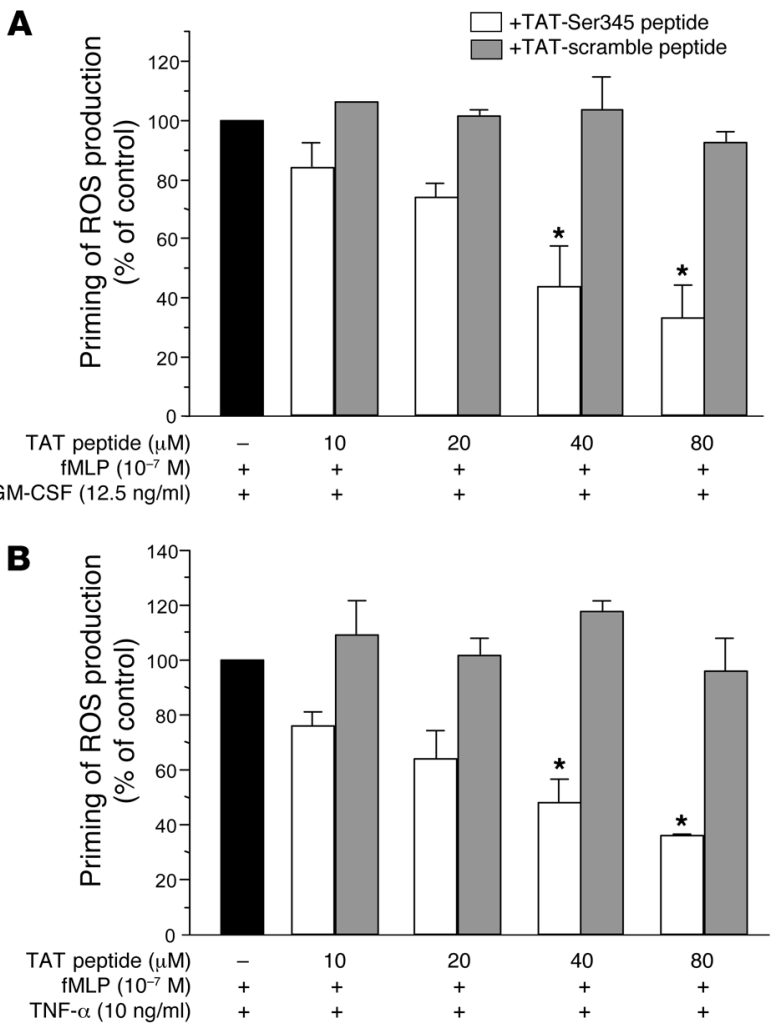

treatment did not significantly differ from that obtained with fMLP alone (Figure 6B). These results show that the Ala-mutated $\mathrm{p} 47 \mathrm{phox}$ acts as a dominant-negative inhibitor of endogenous $\mathrm{p} 47 \mathrm{phox}$ and clearly indicate that phosphorylation of Ser345 is required for the priming of NADPH oxidase activity in neutrophil-like cells.

A cell-permeable peptide containing the Ser345 sequence specifically inhibits the priming effect of GM-CSF and TNF- $\alpha$ on neutrophil ROS production. An alternative strategy to study the role of specific proteins or enzymes in neutrophil functions is to use cell-permeant pharmacologic inhibitors or cell-permeant peptides. To determine whether phosphorylation of Ser345 is directly linked to the priming process in intact cells, we generated an inhibitory cell-permeable peptide (TAT-Ser345 peptide) corresponding to amino acids 339-350 (ARPGPQSPGSPL) of p47phox, linked at the N-terminus to a highly basic peptide (YGRKKRRQRRR) derived from HIV tat protein. This permits peptide translocation across cell membranes (51) and provides a very effective protein delivery method in human neutrophils (52). This peptide is expected to compete with the Ser345 of p47phox as a substrate for ERK1/2 and p38 MAPK. Cells were first treated with the peptide for 30 minutes and then with GM-CSF or TNF- $\alpha$ for 15 minutes before fMLP stimulation. For greater sensitivity, ROS production was measured in terms of luminol-amplified chemiluminescence. As shown in Figure 7, TATSer345 inhibited both GM-CSF- and TNF- $\alpha$-induced priming of the respiratory burst, in a concentration-dependent manner, while the TAT-scramble peptide had little or no inhibitory effect. These results suggest that Ser345 plays a critical role in the priming of neutrophil $\mathrm{O}_{2} .^{-}$production induced by GM-CSF and TNF- $\alpha$.

Priming of NADPH oxidase activity, phosphorylation of $p 47^{\text {phox }}$ on Ser345, and activation of MAPKs in neutrophils from patients with $R A$. Massive neutrophil accumulation at the inflammatory site and

\section{Figure 7}

Effect of a cell-permeable peptide containing the Ser345 sequence on the priming effect of GM-CSF and TNF- $\alpha$ on neutrophil ROS production. Neutrophils were incubated with a cell-permeable peptide corresponding to amino acids 339-350 (ARPGPQSPGSPL) of $\mathrm{p} 47^{\text {phox }}$ (TAT-peptide-Ser345) or with a scramble peptide (TAT-scramble peptide) linked to TAT peptide, for 30 minutes, then with GM-CSF $(\mathbf{A})$ or TNF- $\alpha$ (B) for 20 minutes, before stimulation with $\mathrm{fMLP}\left(10^{-7} \mathrm{M}\right)$. ROS production was measured using a luminol-amplified chemiluminescence technique. Data are presented as mean \pm SEM $(n=4) .{ }^{*} P<0.05$.

massive ROS release are believed to contribute to tissue injury in inflammatory diseases. ROS release can be potentiated by the presence of proinflammatory cytokines such as GM-CSF and TNF- $\alpha$ at the inflammatory site. Because proinflammatory cytokines are involved in several inflammatory diseases, such as RA, and antiTNF- $\alpha$ therapies are very beneficial in this disease, we examined NADPH oxidase priming, p47phox_Ser345 phosphorylation, and ERK1/2 or p38 MAPK phosphorylation status in neutrophils from patients with RA. The results showed (Figure 8A) that neutrophils from synovial fluid of RA patients had higher basal NADPH oxidase activity than neutrophils isolated from blood of the same patient. When stimulated with AMLP, neutrophils from synovial fluid of RA patients had higher ROS production than circulating neutrophils (Figure 8B), suggesting that they were primed. Results obtained from 10 patients are summarized in Figure 8C. Furthermore, phosphorylation of $\mathrm{p} 47^{\text {phox }}$ on Ser345, phosphorylation of ERK1/2, and phosphorylation of p38 MAPK were all increased in RA patients' synovial neutrophils as compared with their blood neutrophils (Figure 9). This result was obtained from 10 different RA patients, but data for only 3 are shown on this figure. In all these experiments, specific detection of p47phox, ERK1/2, and p38 MAPK with specific antibodies that recognize the nonphosphorylated as well as the phosphorylated proteins showed that the same amounts of each protein were present in each sample. Taken together, these results suggest that resident synovial neutrophils from RA patients are in a primed state and that phosphorylation of 447 phox on Ser345 by convergent kinases such as ERK1/2 and p38 MAPK could be the molecular basis of this process.

The cell-permeable peptide TAT-Ser 345 inhibits basal and primed ROS production by neutrophils from RA patients. The effect of the TATSer345 peptide was investigated in this inflammatory disease situation in which neutrophils from synovial fluid are primed and produce high level of ROS. Results showed (Figure 10) that TAT-Ser345 peptide has a strong inhibitory effect on basal ROS production by synovial neutrophils from RA patients even at a low concentration such as $10 \mu \mathrm{M}$. fMLP-stimulated ROS generation of these primed synovial neutrophils was also inhibited by TAT-Ser345 peptide. In contrast, TAT-scramble peptide did not inhibit basal or fMLPstimulated ROS production. This result suggests that TAT-Ser345 peptide could have antiinflammatory properties.

\section{Discussion}

The molecular mechanisms underlying human neutrophil respiratory burst priming are unknown. Phosphorylation of the cytosolic subunit $\mathrm{p} 47 \mathrm{phox}$ is necessary for NADPH oxidase activation and regulation. The proinflammatory cytokines GM-CSF and TNF- $\alpha$ induce partial $447^{\text {phox }}$ phosphorylation in human neutrophils, but the phosphorylated serine remained to be identi- 
A

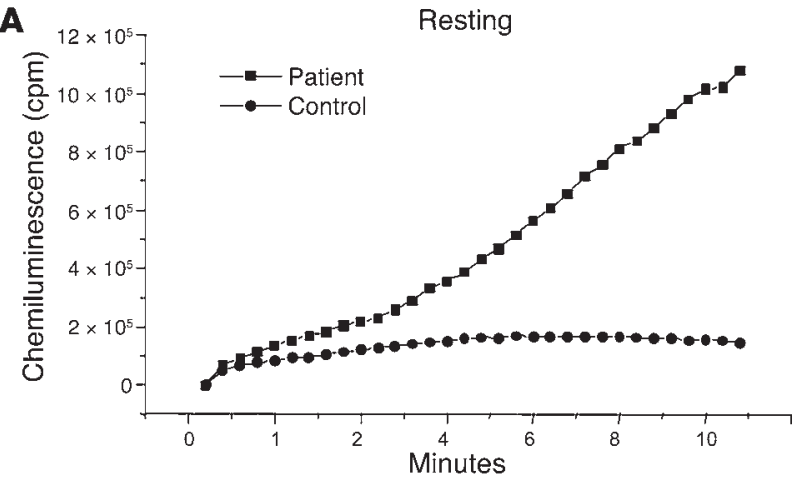

$\mathbf{B}$

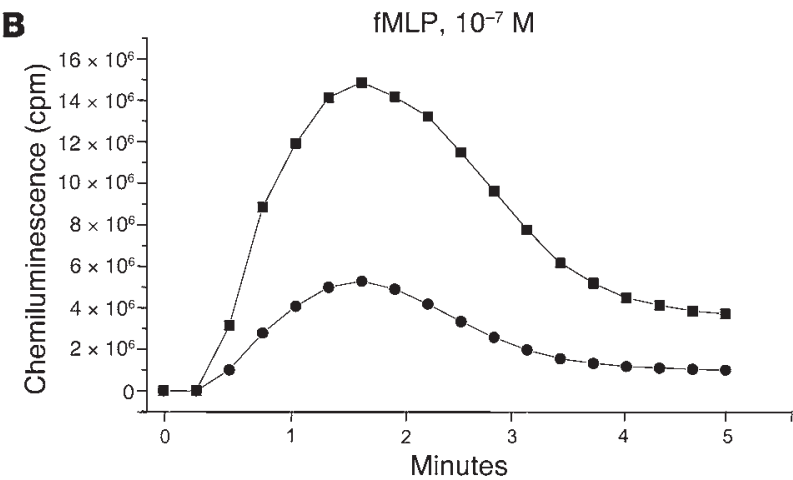

C

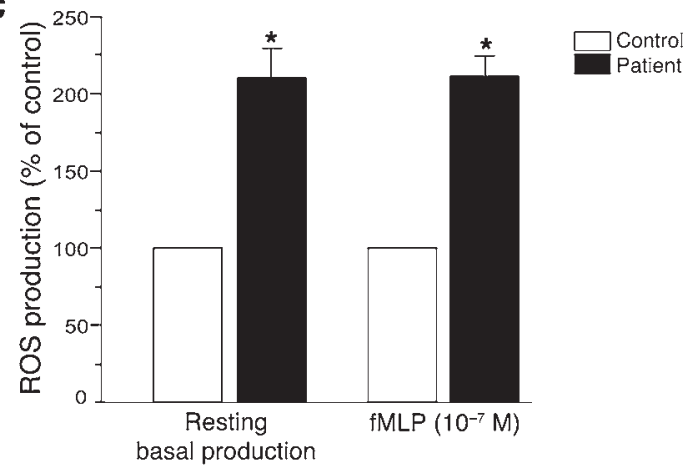

fied, and a direct link to the priming of ROS production remained to be determined. In this study we show that GM-CSF and TNF- $\alpha$ induce $\mathrm{p} 47^{\mathrm{phox}}$ phosphorylation on Ser345. In the respiratory burst priming conditions induced by GM-CSF and TNF- $\alpha$, phosphorylation of this site was markedly higher than in stimulatory conditions created by the chemoattractant peptide AMLP or the protein kinase $\mathrm{C}$ activator PMA. We also show that ERK1/2 are the kinases involved in GM-CSF-induced phosphorylation of Ser345 and that p38 MAPK is the kinase involved in TNF- $\alpha-$ induced phosphorylation of Ser345. Mutation of this serine inhibited GM-CSF- and TNF- $\alpha$-induced ROS priming in HL-60 cells. A cell-permeable peptide containing the Ser345 sequence specifically inhibited the priming effect of GM-CSF and TNF- $\alpha$ on $\mathrm{O}_{2-}^{-}$production by neutrophils in response to fMLP. Furthermore, we show that neutrophils isolated from synovial fluid of RA patients are already primed to produce ROS and this priming state is associated with upregulation of p47phox-Ser345, ERK1/2, and p38 MAPK phosphorylation in this inflammatory disease. Furthermore, the TAT-Ser345 peptide inhibited ROS production by synovial neutrophils of these RA patients. To our knowledge,

\section{Figure 8}

Priming of NADPH oxidase activity in neutrophils isolated from synovial fluid of patients with RA. (A) Resting neutrophils $\left(5 \times 10^{5}\right.$ cells) isolated from blood or from synovial fluid of RA patients were incubated in HBSS in the presence of luminol $(10 \mu \mathrm{M})$, and spontaneous (without stimulation) chemiluminescence was measured over time. (B) The same preparation was then stimulated with fMLP $\left(10^{-7} \mathrm{M}\right)$, and chemiluminescence was measured over time. (C) $\mathrm{O}_{2} \bullet^{--}$production was quantified by cytochrome $c$ reduction assay; control $(100 \%)$ basal $\mathrm{O}_{2} \bullet-$ production was $0.14 \pm 0.01 \mathrm{nmol} / \mathrm{min} / 10^{6}$ cells, and control (100\%) fMLP-induced $\mathrm{O}_{2} \bullet-$ production was $3.6 \pm 0.5$ $\mathrm{nmol} / \mathrm{min} / 10^{6}$ cells. Data are presented as mean \pm SEM $(n=10)$. ${ }^{\star} P<0.05$ compared with control.

this is the first report showing a pivotal role of a specific serine phosphorylated on $\mathrm{p} 47^{\mathrm{phox}}$ by convergent MAPKs in the respiratory burst priming of neutrophils in an inflammatory environment. This phosphorylated site could potentially serve as a pharmacological target in RA and other inflammatory diseases.

In fMLP- or PMA-activated neutrophils, $\mathrm{p} 47^{\mathrm{phox}}$ is phosphorylated on several serines $(17,18)$. Tryptic peptide mapping of $\mathrm{p} 4 \mathrm{p}^{\mathrm{phox}}$ showed that these phosphorylated serines were located on several peptides on the phosphopeptide map. We have shown that GM-CSF induces the phosphorylation of a single major p47phox peptide (29), suggesting that GM-CSF induces partial phosphorylation of $\mathrm{p} 47^{\mathrm{phox}}$ only on certain serines; this might potentiate the phosphorylation of the other serines after secondary fMLP stimulation. The position of the phosphorylated peptides on the $\mathrm{p} 47 \mathrm{phox}$ phosphopeptide map identified serines $345,348,359$, and 370 as candidate targets for GM-CSF-induced phosphorylation. In this study, MS/MS analysis identified Ser345 as the phosphorylated serine. It is noteworthy that 2-dimensional phosphopeptide mapping of phosphorylated 447 phox in TNF- $\alpha$-primed neutrophils revealed partial phosphorylation of $\mathrm{p} 47 \mathrm{phox}$ on the same peptide as in GM-CSF-exposed neutrophils (30), suggesting that the same phosphorylated site is targeted during priming. Indeed, our results show that phosphorylation of Ser345 is also induced by TNF- $\alpha$. To our surprise, Ser345 was only moderately phosphorylated in neutrophils stimulated with AMLP or PMA, suggesting that phosphorylation of this site is selectively targeted by priming conditions. A cell-permeable peptide containing the Ser345 sequence specifically inhibited the priming effect of GM-CSF and TNF- $\alpha$ on neutrophil $\mathrm{O}_{2}{ }^{-}$production, suggesting that Ser345 phosphorylation plays a functional role by potentiating NADPH oxidase activation. Mutation studies of $\mathrm{p} 47^{\text {phox }}$ serines in EBV-transformed lymphoblasts (19) showed that mutation of Ser345 to Ala had only a moderate effect on PMA-induced $\mathrm{O}_{2} .^{-}$production. Our results are in keeping with these data, showing that phosphorylation of Ser345 was weakly induced by PMA, and also lend further weight to the hypothesis that Ser345 is specifically induced and has a role in the priming process.

As Ser345 is located in the MAPK phosphorylation consensus sequence (-PXSP-), we tested the effects of MAPK inhibitors on this phosphorylation. We found that PD98059 and UO126, which inhibit MEK1/2 (the upstream activator of

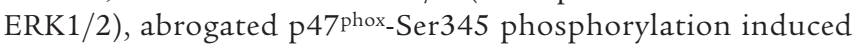
by GM-CSF, while SB203580, an inhibitor of p38 MAPK, had no inhibitory effect. On the other hand, in TNF- $\alpha$-treated neu-

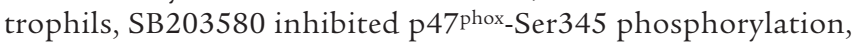
but PD98059 and UO126 had no effect. As p47phox is a good in 


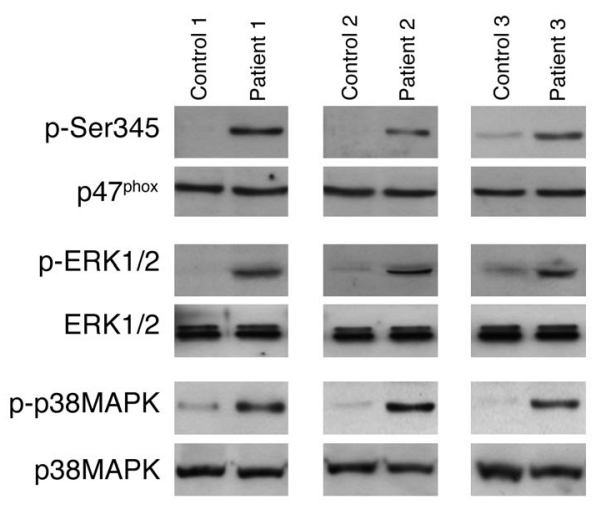

vitro substrate for ERK2 and P38 MAPK $(53,54)$, these 2 kinases could target 447 phox in intact neutrophils when recruited by specific agonists (GM-CSF and TNF- $\alpha$, respectively). In addition, inhibitors of ERK1/2 and p38 MAPK inhibited neutrophil respiratory burst priming by GM-CSF and TNF- $\alpha$ (data not shown and refs. $27,31,39,40)$. These results strongly suggest that ERK1/2 are the kinases that mediate p47phox phosphorylation on Ser345 in GM-CSF-treated neutrophils and that p38 MAPK is the kinase that mediates $\mathrm{p} 47^{\text {phox }}$ phosphorylation on Ser345 in TNF- $\alpha$-treated neutrophils. Ser345 serves as a point of convergence of different MAPKs to prime ROS production. Several reports suggest that phosphorylation of $\mathrm{p} 47$ phox induces conformational changes (55-57) that initiate assembly of the active enzyme via interaction of the $\mathrm{SH} 3$ domains with the proline-rich region of $\mathrm{p}^{22^{\text {phox }}} \cdot \mathrm{p} 47^{\text {phox }}$ contains $2 \mathrm{SH} 3$ domains, one of which interacts intramolecularly with a $\mathrm{p}^{4} 7^{\text {phox }}$-polyproline sequence in the nonphosphorylated protein. This interaction

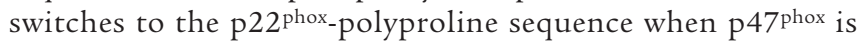
phosphorylated. Pre-phosphorylation of 447 phox on Ser345 by ERK1/2 or p38 MAPK could facilitate conformational changes induced by a secondary phosphorylation step.

\section{Figure 9}

Phosphorylation of p47 phox on Ser345 and phosphorylation of ERK1/2 and p38 MAPK are increased in neutrophils isolated from synovial fluid of patients with RA. Resting neutrophils $\left(5 \times 10^{5}\right.$ cells) isolated from blood or from synovial fluid of RA patients were lysed, and proteins were analyzed with SDS-PAGE and immunoblotting with anti-phospho-Ser345 antibody, anti-phospho-ERK1/2, or anti-phospho-p38 antibody. Total p47phox, ERK1/2, and p38 MAPK were detected using specific antibody. Results from 3 of 10 RA patients are shown.
We compared NADPH oxidase activation in circulating and synovial neutrophils from RA patients. Neutrophils isolated from synovial fluid showed a stronger oxidative burst than neutrophils isolated from peripheral blood of the same patients and of healthy controls. These results showed that the patients' synovial neutrophils were primed. In addition, p47phox-Ser345 phosphorylation and the MAPKs (ERK1/2 and p38) that mediate this process were upregulated. These results suggest that increased NADPH oxidase activity and excessive ROS generation could be involved in arthritic joint inflammation and destruction, through increased p47phox-Ser345 phosphorylation. This would be related to high levels of proinflammatory cytokines in synovial fluid, such as TNF- $\alpha$, GM-CSF, IL-8, or other agents that activate ERK1/2 or p38 MAPK. Additionally, the high levels of TNF- $\alpha$ in synovial fluid from RA patients, along with the beneficial effect of anti-TNF- $\alpha$ therapies in this rheumatic disease, strongly support a pivotal action of this cytokine in the pathogenesis of the joint lesions. The effect of TAT-Ser345 peptide was tested on neutrophils from synovial fluid of RA patients. It is noteworthy that TAT-Ser345 peptide has a strong inhibitory effect on basal ROS production by neutrophils from RA patients even at low concentration. fMLP-stimulated

\section{Figure 10}

The cell-permeable peptide TAT-Ser345 inhibits the basal and primed ROS production by neutrophils from patients with RA. Neutrophils isolated from RA patients $\left(5 \times 10^{5}\right)$ were incubated with a cell-permeable peptide corresponding to TAT-peptide-Ser345 sequence or with a scramble peptide for 30 minutes, then ROS production was measured with the luminol-amplified chemiluminescence technique in the absence $(\mathbf{A})$ or presence $(\mathbf{B})$ of fMLP $\left(10^{-7} \mathrm{M}\right)$. Data are presented as mean \pm SEM $(n=3)$. ${ }^{\star} P<0.05$.
A

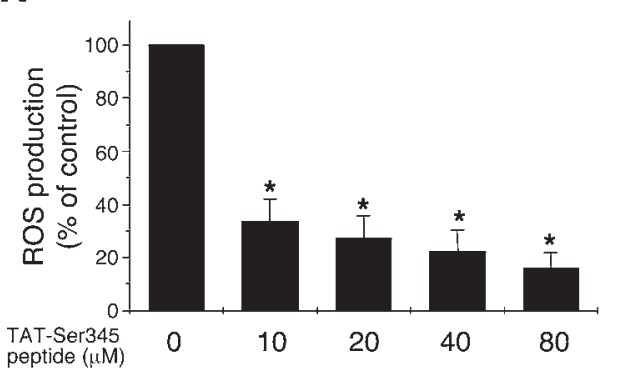

Basal production

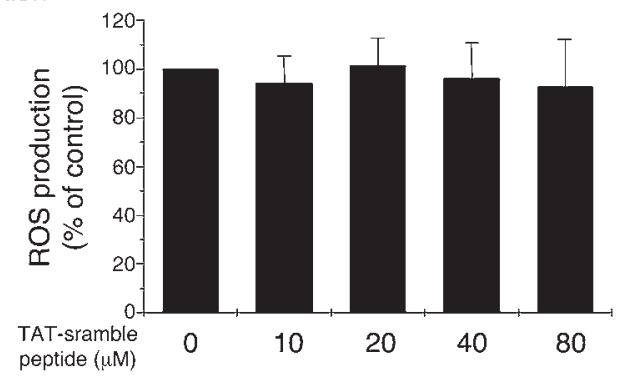

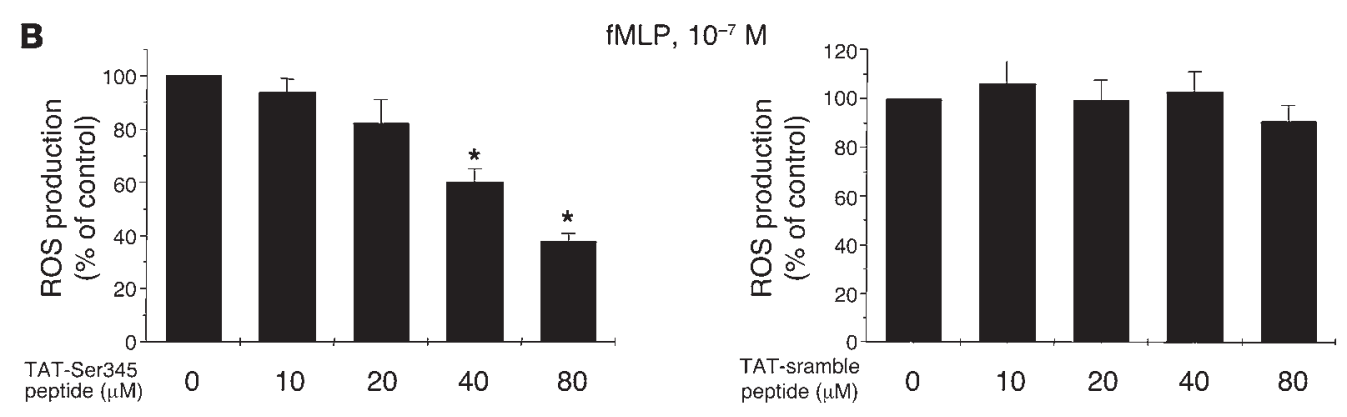


ROS generation by primed neutrophils from RA patients was also inhibited. This result suggests that Ser345 could be continuously phosphorylated/dephosphorylated in inflammatory conditions and this inhibitory peptide could have antiinflammatory properties involving inhibition of the phosphorylation process.

In conclusion, this study shows that, in respiratory burst priming conditions, GM-CSF and TNF- $\alpha$ induce p47phox phosphorylation on Ser345, while stimulation with the bacterial $\mathrm{N}$-formyl peptide fMLP has much weaker effects. Phosphorylation of this site can be mediated by ERK1/2 (in GM-CSF-primed cells) or by p38 MAPK (in TNF- $\alpha$-primed cells). A cell-permeable peptide containing the Ser345 sequence specifically inhibited the priming effect of GM-CSF and TNF- $\alpha$ on ROS production. Furthermore, neutrophils isolated from synovial fluid of RA patients were found to be primed for ROS production and exhibited specific phosphorylation of $\mathrm{p} 47 \mathrm{P}^{\mathrm{phx}}$ on Ser345, as well as upregulation of both ERK1/2 and p38 MAPK phosphorylation. The TAT-Ser345 peptide inhibited ROS production by synovial neutrophils of these patients. These results strongly suggest that Ser345 serves as a point of convergence of different MAPKs to induce priming of ROS production. Pharmacological inhibition of this common phosphorylation site on p47phox might avoid exaggerated neutrophil responses in inflammatory environments while preserving the physiological ability of the bacterial $\mathrm{N}$-formyl peptides to activate neutrophils.

\section{Methods}

Reagents and antibodies. Recombinant human GM-CSF and TNF- $\alpha$ were from R\&D Systems and PeproTech. The FMLP, PMA, and protease and phosphatase inhibitors were from Sigma-Aldrich. [32P]orthophosphoric acid was from PerkinElmer. Kinase inhibitors were from Calbiochem. Injection-grade water and $0.9 \% \mathrm{NaCl}$ were endotoxin-free in the limulus test (Charles River Laboratories). Endotoxin-free buffers and salt solutions were from Invitrogen. Rabbit polyclonal antibody against $\mathrm{p} 47^{\mathrm{phox}}$ was a generous gift from B.M. Babior (The Scripps Research Institute, La Jolla, California, USA). For the production of an antibody directed against phospho-Ser345, rabbits were injected with the ovalbumin-crosslinked phosphopeptide sequence of p47phox [QARPGPQS(phospho)PGSPL EEE], produced by Neosystem and Multiple Peptides Systems. The peptides used in this study, corresponding to amino acids 339-350 (ARPGPQSPGSPL) of $47^{\text {phox }}$ (TAT-peptide-Ser345) and a control scramble peptide (PRGLAPSGQPS) (TAT-scramble peptide) linked at the N-terminus to a highly basic peptide (YGRKKRRQRRR) derived from HIV tat protein, were synthesized by Neosystems and Multiple Peptides Systems.

Neutrophil preparation and 447 phox immunoprecipitation. Human neutrophils were obtained in LPS-free conditions by means of dextran sedimentation and Ficoll centrifugation as previously described (29). Neutrophils in HBSS $\left(25 \times 10^{6} / \mathrm{ml}\right)$ were treated with GM-CSF $(12 \mathrm{ng} / \mathrm{ml})$ or TNF- $\alpha(10$ $\mathrm{ng} / \mathrm{ml}$ ) at $37^{\circ} \mathrm{C}$ for 20 minutes, which corresponds to optimal conditions to prime the respiratory burst in response to $\operatorname{fMLP}(29,30)$. The reaction was stopped by adding ice-cold buffer and by centrifugation at $400 \mathrm{~g}$ for 6 minutes at $4^{\circ} \mathrm{C}$. The cells were lysed by resuspension in lysis buffer $(20$ $\mathrm{mM}$ Tris-HCl $\mathrm{pH}$ 7.4, $150 \mathrm{mM} \mathrm{NaCl}, 0.25 \mathrm{M}$ sucrose, 5 mM EGTA, $5 \mathrm{mM}$ EDTA, $15 \mu \mathrm{g} / \mathrm{ml}$ leupeptin, $10 \mu \mathrm{g} / \mathrm{ml}$ pepstatin, $10 \mu \mathrm{g} / \mathrm{ml}$ aprotinin, 1.5 mM PMSF, 1 mM diisopropyl fluorophosphate, 0.5\% Triton X-100, 25 mM $\mathrm{NaF}, 5 \mathrm{mM} \mathrm{NaVO}_{4}, 5 \mathrm{mM} \beta$-glycerophosphate, $1 \mathrm{mM}$ p-nitrophenyl phosphate, $1 \mathrm{mg} / \mathrm{ml}$ DNase I) and sonication on ice $(3 \times 15 \mathrm{~s})$; the lysate was then centrifuged at $100,000 \mathrm{~g}$ for 30 minutes at $4^{\circ} \mathrm{C}$ in a TL100 ultracentrifuge (Beckman Coulter). The cleared supernatant was incubated overnight with anti-p47phox (1:200), and protein was immunoprecipitated with GammaBind G Sepharose beads (GE Healthcare), washed 4 times in lysis buffer, and denatured in Laemmli sample buffer. The samples were subjected to SDS-PAGE in $10 \%$ polyacrylamide gels, using standard techniques (58). The separated proteins were stained with Coomassie blue, and the protein band corresponding to $\mathrm{p} 47^{\mathrm{phox}}$ was cut out, treated with protease, and analyzed by mass spectrometry as described below.

Preparation of $p^{4} 7^{\text {phox }}$ samples and automated nanoflow LC-MS/MS analysis. P47Phox was isolated by SDS PAGE, stained with Coomassie blue, and digested in situ with trypsin and LysC. Extracted peptide mixtures were analyzed with a nanoflow capillary high-pressure liquid chromatography system (UltiMate; LC Packings) directly coupled to a Q-Tof tandem mass spectrometer (Q-Tof Ultima API; Waters) as described previously (46). Peptide mixtures were separated on a 9-cm custom-packed C18 reversephase column (75 $\mu \mathrm{m}$ ID ZORBAX SB-C18; Agilent Technologies; $3.5-\mu \mathrm{m}$ particle size) during a 35 -minute gradient of $0-90 \%$ acetonitrile ( $\mathrm{vol} / \mathrm{vol}$ ) containing $1 \%(\mathrm{vol} / \mathrm{vol}$ ) formic acid, $0.6 \%$ (vol/vol) acetic acid, and $0.005 \%$ ( vol/vol) heptafluorobutyric acid at a flow rate of $175 \mathrm{nl} / \mathrm{min}$. The mass spectrometer was calibrated with $\mathrm{NaI}$.

Mass spectra obtained by automated nanoflow LC-MS/MS, and datadependent acquisition modes were analyzed with MassLynx 3.5 software (Waters) and Mascot MS/MS Ions Search software (Matrix Science). Tandem mass spectra obtained with phosphopeptides were manually inspected and compared with theoretical data obtained using the GPMAW 6.20 program (Lighthouse data).

${ }^{32}$ P labeling, stimulation, and fractionation of neutrophils. Cells were incubated in phosphate-free buffer (20 mM HEPES pH 7.4, $140 \mathrm{mM} \mathrm{NaCl}, 5.7 \mathrm{mM} \mathrm{KCl}$, $0.8 \mathrm{mM} \mathrm{MgCl}_{2}$, and $0.025 \% \mathrm{BSA}$ ) containing $0.5 \mathrm{mCi}\left[{ }^{32} \mathrm{P}\right]$ orthophosphoric acid $/ 10^{8}$ cells $/ \mathrm{ml}$ for 60 minutes at $30^{\circ} \mathrm{C}$, as previously reported (29). Cells were then treated with GM-CSF or TNF- $\alpha$. The reaction was stopped by adding ice-cold buffer and centrifugation at $400 \mathrm{~g}$ for 6 minutes at $4^{\circ} \mathrm{C}$. The cells were lysed, and $\mathrm{p} 47^{\mathrm{phox}}$ was immunoprecipitated as described above. The samples were subjected to SDS-PAGE in $10 \%$ polyacrylamide gels, using standard techniques. The separated proteins were transferred to nitrocellulose and detected as described previously (29).

Detection of Ser 345 phosphorylation in neutrophils by a specific antibody. Neutrophils $\left(1 \times 10^{7} \mathrm{cells} / \mathrm{ml}\right)$ were incubated with various concentrations of GM-CSF, TNF- $\alpha$, fMLP, or PMA or at different incubation times. Cells were lysed in the lysis buffer as described above, and proteins from $4 \times 10^{5}$ cells were analyzed with SDS-PAGE and immunoblotting with anti-phospho-Ser345 antibody (1:10,000 dilution) or anti-p47phox antibody (1:5,000 dilution) and HRP-labeled goat anti-rabbit antibody. The reaction was detected using ECL reagents.

HL-60 cell culture, transfection, and differentiation. HL-60 cells were purchased from ATCC and cultured in RPMI-1640 containing 10\% heat-inactivated fetal bovine serum, $100 \mathrm{U} / \mathrm{ml}$ penicillin, $100 \mu \mathrm{g} / \mathrm{ml}$ streptomycin at $37^{\circ} \mathrm{C}$ in humidified atmosphere, $5 \% \mathrm{CO}_{2}$ in air. Plasmids (pEBO) that encode WT $447^{\text {phox }}$ or $\mathrm{p}^{4} 7^{\text {phox }}$ in which Ser345 was mutated to alanine (S345A) were constructed as we have described $(18,19)$ (gift from B. Babior). HL-60 cells were transfected by electroporation using the same protocol as for B cells (59). After 48 hours, hygromycin B was added to a final concentration of $200 \mu \mathrm{g} / \mathrm{ml}$, and the cells were grown under hygromycin B selection pressure for 2 weeks. p47phox protein expression in transfected HL-60 cells was monitored by Western blotting. For differentiation, exponentially growing cells were harvested and resuspended at a density of $5 \times 10^{5} \mathrm{cells} / \mathrm{ml}$ in complete medium with hygromycin B in the presence of $1.3 \%$ DMSO. After 5 days, the cells were washed and incubated for 5 hours in RPMI alone, then assessed for NADPH oxidase activity using chemiluminescence.

Preparation of neutrophils from synovial fluid and peripheral blood from $R A$ patients. With the subjects' informed consent, knee-joint synovial fluid and peripheral blood were collected from patients who met the American College of Rheumatology criteria for RA $(60,61)$ and who did not receive any 
anti-cytokine biotherapy. Samples were collected in sterile lithium heparinate tubes. To make sure that neutrophil preparation was performed in the same conditions and at the same time, synovial fluid and venous blood were diluted twice in sterile PBS and cells were isolated by 1-step centrifugation using a Polymorphprep gradient (Abcys SA; Axis-Shield). After centrifugation at $500 \mathrm{~g}$ for 30 minutes at $22^{\circ} \mathrm{C}$, the neutrophil band was collected and cells washed in PBS and counted, then used for ROS production and Western blots.

Measurement of $\mathrm{O}_{2}-$ and ROS production. $\mathrm{O}_{2--}$ production was measured in response to fMLP $\left(10^{-7} \mathrm{M}\right)$ in terms of $\mathrm{O}_{2}{ }^{-}$dismutase-inhibitable ferricytochrome $c$ reduction as described previously (29) or the chemiluminescence method: cells $\left(2.5 \times 10^{5}\right)$ were suspended in $0.5 \mathrm{ml}$ HBSS containing $10 \mu \mathrm{M}$ luminol preheated to $37^{\circ} \mathrm{C}$ in the thermostated chamber of the luminometer (Biolumat LB937; Berthold). After a baseline reading, cells were stimulated with $10^{-7} \mathrm{M}$ fMLP, and chemiluminescence was recorded.
Statistics. All results are expressed as mean \pm SEM. Significant differences were identified using 2 -tailed Student's $t$ test; $P<0.05$ was considered significant.

\section{Acknowledgments}

This work was supported by a grant from Association de la Recherche sur la Polyarthrite (ARP), INSERM, and CNRS.

Received for publication November 30, 2005, and accepted in revised form April 18, 2006.

Address correspondence to: Jamel El-Benna, INSERM U.773, Faculté de Medecine Xavier Bichat, 16 rue Henri Huchard, 75018 Paris, France. Phone: 33-140-25-85-21; Fax: 33-144-85-62-07; E-mail: benna@bichat.inserm.fr.
1. Babior, B.M. 2000. Phagocytes and oxidative stress. Am. J. Med. 109:33-44.

2. Klebanoff, S.J. 2005. Myeloperoxidase: friend and foe. J. Lenkoc. Biol. 77:598-625.

3. Segal, A.W. 2005. How neutrophils kill microbes. Annu. Rev. Immunol. 23:197-223.

4. Babior, B.M. 1984. Oxidants from phagocytes: agents of defense and destruction. Blood. 64:959-966.

5. Chanock, S.J., El-Benna, J., Smith, R.M., and Babior, B.M. 1994. The respiratory burst oxidase. J. Biol. Chem. 269:24519-24522.

6. Quinn, M.T., and Gauss, K.A. 2004. Structure and regulation of the neutrophil respiratory burst oxidase: comparison with nonphagocyte oxidases. J. Leukoc. Biol. 76:760-781.

7. Groemping, Y., and Rittinger, K. 2005. Activation and assembly of the NADPH oxidase: a structural perspective. Biochem. J. 386:401-416

8. Clark, R.A., Volpp, B.D., Leidal, K.G., and Nauseef, W.M. 1990. Two cytosolic components of the human neutrophil respiratory burst oxidase translocate to the plasma membrane during cell activation. J. Clin. Invest. 85:714-721.

9. Quinn, M.T., Evans, T., Loetterle, L.R., Jesaitis, A.J., and Bokoch, G.M. 1993. Translocation of Rac correlates with NADPH oxidase activation. Evidence for equimolar translocation of oxidase components. J. Biol. Chem. 268:20983-20987.

10. Abo, A., Webb, M.R., Grogan, A., and Segal, A.W. 1994. Activation of NADPH oxidase involves the dissociation of p21 rac from its inhibitory GDP/ GTP exchange protein (rhoGDI) followed by its translocation to the plasma membrane. Biochem. J. 298:585-591.

11. El Benna, J., Ruedi, J.M., and Babior, B.M.1994. Cytosolic guanine nucleotide-binding protein Rac 2 operates in vivo as a component of the neutrophil respiratory burst oxidase. Transfer of Rac 2 and the cytosolic oxidase components $\mathrm{p} 47 \mathrm{phox}$ and p67phox to the submembranous actin cytoskeleton during oxidase activation. J. Biol. Chem. 269:6729-6734.

12. Okamura, N., Curnutte, J.T., Roberts, R.L., and Babior, B.M. 1988. Relationship of protein phosphorylation to the activation of the respiratory burst in human neutrophils. Defects in the phosphorylation of a group of closely related $47-\mathrm{kDa}$ proteins in two forms of chronic granulomatous disease. J. Biol. Chem. 263:6777-6782.

13. Dusi, S., and Rossi, F. 1993. Activation of NADPH oxidase of human neutrophils involves the phosphorylation and the translocation of cytosolic p67phox. Biochem. J. 296:367-371.

14. El-Benna, J., et al. 1997. Phosphorylation of the respiratory burst oxidase subunit p67phox during human neutrophil activation. Regulation by protein kinase C-dependent and independent pathways. J. Biol. Chem. 272:17204-17208.
15. Bouin, A.P., Grandvaux, N., Vignais, P.V., and Fuchs, A. 1998. p40(phox) is phosphorylated on threonine 154 and serine 315 during activation of the phagocyte NADPH oxidase. Implication of a protein kinase c-type kinase in the phosphorylation process. J. Biol. Chem. 273:30097-30103.

16. Regier, D.S., Greene, D.G., Sergeant, S., Jesaitis, A.J., and McPhail, L.C. 2000. Phosphorylation of p22phox is mediated by phospholipase D-dependent and independent mechanisms. Correlation of NADPH oxidase activity and p22phox phosphorylation. J. Biol. Chem. 275:28406-28412.

17. El Benna, J., Faust, L.P., and Babior, B.M. 1994. The phosphorylation of the respiratory burst oxidase component $\mathrm{p} 47$ phox during neutrophil activation. Phosphorylation of sites recognized by protein kinase $\mathrm{C}$ and by proline-directed kinases. J. Biol. Chem. 269:23431-23436.

18. El Benna, J., Faust, L.P., Johnson, J.L., and Babior, B.M. 1996. Phosphorylation of the respiratory burst oxidase subunit $\mathrm{p} 47 \mathrm{phox}$ as determined by two-dimensional phosphopeptide mapping. Phosphorylation by protein kinase $\mathrm{C}$, protein kinase $\mathrm{A}$, and a mitogen-activated protein kinase. J. Biol. Chem. 271:6374-6378.

19. Faust, L.P., El Benna, J., Babior, B.M., and Chanock, S.J. 1995. The phosphorylation targets of p47phox, a subunit of the respiratory burst oxidase. Functions of the individual target serines as evaluated by site-directed mutagenesis. J. Clin. Invest. 96:1499-1505.

20. Downey, G.P., Fukushima, T., Fialkow, L., and Waddell, T.K. 1995. Intracellular signaling in neutrophil priming and activation. Semin. Cell Biol. 6:345-356.

21. Hallett, M.B., and Lloyds, D.L. 1995. Neutrophil priming: the cellular signals that say 'amber' but not 'green.' Immunol. Today. 16:264-268.

22. Elbim, C., Bailly, S., Chollet-Martin, S., Hakim, J., and Gougerot-Pocidalo, M.A. 1994. Differential priming effects of proinflammatory cytokines on human neutrophil oxidative burst in response to bacterial $\mathrm{N}$-formyl peptides. Infect. Immun. 62:2195-2201

23. Elbim, C., Chollet-Martin, S., Bailly, S., Hakim, J., and Gougerot-Pocidalo, M.A. 1993. Priming of polymorphonuclear neutrophils by tumor necrosis factor alpha in whole blood: identification of two polymorphonuclear neutrophil subpopulations in response to formyl-peptides. Blood. 82:633-640.

24. McColl, S.R., Beauseigle, D., Gilbert, C., and Naccache, P.H. 1990. Priming of the human neutrophil respiratory burst by granulocyte-macrophage colony-stimulating factor and tumor necrosis factor-alpha involves regulation at a post-cell surface receptor level. Enhancement of the effect of agents which directly activate $\mathrm{G}$ proteins. J. Immunol. 145:3047-3053.

25. Keil, M.L., et al. 2003. Priming-induced localization of $\mathrm{G}($ ialpha2) in high density membrane microdomains. Biochem. Biophys. Res. Commun. 301:862-872.

26. DeLeo, F.R., et al. 1998. Neutrophils exposed to bacterial lipopolysaccharide upregulate NADPH oxidase assembly. J. Clin. Invest. 101:455-463.

27. Ward, R.A., Nakamura, M., and McLeish, K.R. 2000. Priming of the neutrophil respiratory burst involves p38 mitogen-activated protein kinase-dependent exocytosis of flavocytochrome b558-containing granules. J. Biol. Chem. 275:36713-36719.

28. Mansfield, P.J., Hinkovska-Galcheva, V., Shayman, J.A., and Boxer, L.A. 2002. Granulocyte colony-stimulating factor primes NADPH oxidase in neutrophils through translocation of cytochrome $\mathrm{b}(558)$ by gelatinase-granule release. J. Lab. Clin. Med. 140:9-16.

29. Dang, P.M., et al. 1999. Priming of human neutrophil respiratory burst by granulocyte/macrophage colony-stimulating factor (GM-CSF) involves partial phosphorylation of p47phox. J. Biol. Chem. 274:20704-20708.

30. Dewas, C., Dang, P.M., Gougerot-Pocidalo, M.-A., and El-Benna, J. 2003. TNF induces phosphorylation of $\mathrm{p} 47 \mathrm{phox}$ in human neutrophils: partial phosphorylation of $\mathrm{p} 47 \mathrm{phox}$ is a common event of priming of human neutrophils by TNF and granulocyte-macrophage colony-stimulating factor. J. Immunol. 171:4392-4398.

31. Brown, G.E., et al. 2004. Distinct ligand-dependent roles for p38 MAPK in priming and activation of the neutrophil NADPH oxidase. J. Biol. Chem. 279:27059-27068.

32. Miyajima, A., Mui, A.L., Ogorochi, T., and Sakamaki, K. 1993. Receptors for granulocyte-macrophage colony-stimulating factor, interleukin-3, and interleukin-5. Blood. 82:1960-1974.

33. Bagley, C.J., Woodcock, J.M., Stomski, F.C., and Lopez, A.F. 1997. The structural and functional basis of cytokine receptor activation: lessons from the common beta subunit of the granulocyte-macrophage colony-stimulating factor, interleukin-3 (IL-3), and IL-5 receptors. Blood. 89:1471-1482.

34. Corey, S., et al. 1993. Granulocyte macrophagecolony stimulating factor stimulates both association and activation of phosphoinositide $3 \mathrm{OH}$ kinase and src-related tyrosine kinase(s) in human myeloid derived cells. EMBO J. 12:2681-2690.

35. Al-Shami, A., and Naccache, P.H. 1999. Granulocyte-macrophage colony-stimulating factor-activated signaling pathways in human neutrophils. Involvement of Jak 2 in the stimulation of phosphatidylinositol 3-kinase. J. Biol. Chem. 274:5333-5338.

36. Kodama, T., Hazeki, K., Hazeki, O., Okada, T., and Ui, M. 1999. Enhancement of chemotactic peptideinduced activation of phosphoinositide 3-kinase by granulocyte-macrophage colony-stimulating factor and its relation to the cytokine-mediated priming of neutrophil superoxide-anion production. Bio- 
chem. J. 337:201-209.

37. Gomez-Cambronero, J., et al. 1992. Granulocytemacrophage colony-stimulating factor-induced protein tyrosine phosphorylation of microtubuleassociated protein kinase in human neutrophils. Proc. Natl. Acad. Sci. U. S. A. 89:7551-7555.

38. Durstin, M., Durstin, S., Molski, T.F.P., Becker, E.L., and Sha'Afi, R.I. 1994. Cytoplasmic phospholipase A2 translocates to membrane fraction in human neutrophils activated by stimuli that phosphorylate mitogen-activated protein kinase. Proc. Natl. Acad. Sci. U. S. A. 91:3142-3146.

39. McLeish, K.R., et al. 1998. Activation of mitogenactivated protein kinase cascades during priming of human neutrophils by TNF and GM-CSF. J. Lewkoc. Biol. 64:537-545.

40. Suzuki, K., Hino, M., Hato, F., Tatsumi, N., and Kitagawa, S. 1999. Cytokine-specific activation of distinct mitogen-activated protein kinase subtype cascades in human neutrophils stimulated by granulocyte colony-stimulating factor, granulocyte-macrophage colony-stimulating factor, and tumor necrosis factor-alpha. Blood. 93:341-349.

41. Brizzi, M.F., et al. 1996. Granulocyte-macrophage colony-stimulating factor stimulates JAK2 signaling pathway and rapidly activates p93fes, STAT1 p91, and STAT3 92 in polymorphonuclear leukocytes. J. Biol. Chem. 271:3562-3567.

42. Al-Shami, A., Mahanna, W., and Naccache, P.H. 1998. Granulocyte-macrophage colony-stimulating factor-activated signaling pathways in human neutrophils. Selective activation of Jak2, Stat3, and Stat5b. J. Biol. Chem. 273:1058-1063.

43. Aggarwal, B.B., and Natarajan, K. 1996. Tumor necrosis factors: developments during the last decade. Eur. Cytokine Netw. 7:93-124.

44. Firestein, G.S., and Zvaifler, N.J. 1992. Rheuma- toid arthritis: a disease of disordered immunity. In Inflammation: basic principles and clinical correlates. 2nd edition. J.I. Gallin, I.M. Goldstein, and R. Snyderman, editors. Raven Press. New York, New York, USA. 959-977.

45. Smith, J.A. 1994. Neutrophils, host defense, and inflammation: a double-edged sword. J. Leukoc. Biol. 56:672-686.

46. Elortza, F., et al. 2003. Proteomic analysis of glycosylphosphatidylinositol-anchored membrane proteins. Mol. Cell. Proteom. 2:1261-1270.

47. Mann, M., et al. 2002. Analysis of protein phosphorylation using mass spectrometry: deciphering the phosphoproteome. Trend. Biotechnol. 20:261-268.

48. Alessi, D.R., Cuenda, A., Cohen, P., Dudley, D.T., and Saltiel, A.R. 1995. PD098059 is a specific inhibitor of the activation of mitogen-activated protein kinase kinase in vitro and in vivo. J. Biol. Chem. 270:27489-27494.

49. Favata, M.F., et al. 1998. Identification of a novel inhibitor of mitogen activated protein kinase kinase (MEK). J. Biol. Chem. 273:18623-18632.

50. Cuenda, A., et al. 1995. SB203580 is a specific inhibitor of a MAP kinase homologue which is stimulated by cellular stresses and interleukin-1. FEBS Lett. 364:229-233.

51. Nagahara, H., et al. 1998. Transduction of fulllength TAT fusion proteins into mammalian cells: TAT-p27Kip1 induces cell migration. Nat. Med. 4:1449-1452.

52. Han, H., Fuortes, M., and Nathan, C. 2003. Critical role of the carboxyl terminus of proline-rich tyrosine kinase (Pyk2) in the activation of human neutrophils by tumor necrosis factor: separation of signals for the respiratory burst and degranulation. J. Exp. Med. 197:63-75.

53. El Benna, J., et al. 1996. Activation of p38 in stimu- lated human neutrophils: phosphorylation of oxidase component p47phox by p38 and ERK but not by JNK. Arch. Biochem. Biophys. 334:395-400.

54. Manke, I.A., et al. 2005. MAPKAP kinase- 2 is a cell cycle checkpoint kinase that regulates the G2/M transition and $S$ phase progression in response to UV irradiation. Mol. Cell. 17:37-48.

55. Park, H.-S., and Park, J.-W. 1998. Conformational changes of leukocyte NADPH oxidase subunit p47phox during activation studied through its intrinsic fluorescence. Biochim. Biophys. Acta. 1387:406-411.

56. Swain, S.D., Helgerson, S.L., Davis, A.R., Nelson, L.K., and Quinn, M.T. 1997. Analysis of activationinduced conformational changes in $\mathrm{p} 47 \mathrm{phox}$ using tryptophan fluorescence spectroscopy. J. Biol. Chem. 272:29502-29509.

57. Groemping, Y., Lapouge, K., Smerdon, S.J., and Rittinger, K. 2003. Molecular basis of phosphorylation-induced activation of the NADPH oxidase. Cell. 113:343-355.

58. Laemmli, U.K. 1970. Cleavage of structural proteins during the assembly of the head of bacteriophage T4. Nature. 227:680-685.

59. Chanock, S.J., et al. 1992. O2- production by B lymphocytes lacking the respiratory burst oxidase subunit $\mathrm{p} 47 \mathrm{phox}$ after transfection with an expression vector containing a 47 phox cDNA. Proc. Natl. Acad. Sci. U. S. A. 89:10174-10177.

60. Arnett, F.C., et al. 1988. The American Rheumatism Association 1987 revised criteria for the classification of rheumatoid arthritis. Arthritis Rheum. 31:315-324.

61. Dougados, M., et al. 1991. The European Spondylarthropathy Study Group preliminary criteria for the classification of spondylarthropathy. Arthritis Rheum. 34:1218-1227. 